\title{
Carbon dynamics of Deep Bay, eastern Pearl River estuary, China. II: Trophic relationship based on carbon- and nitrogen-stable isotopes
}

\author{
S. Y. Lee* \\ The Swire Institute of Marine Science and Department of Ecology and Biodiversity, The University of Hong Kong, \\ Pokfulam Road, Hong Kong, China
}

\begin{abstract}
A study of the sources of nutrients supporting the consumer community in Deep Bay, a shallow mangrove-fringed embayment in the eastern Pearl River estuary, was conducted using the stable isotopes of carbon and nitrogen. The $\delta^{13} \mathrm{C}$ and $\delta^{15} \mathrm{~N}$ signatures of the potential natural (3 species of mangroves, macroalgae, benthic microalgae, seston in mangrove creeks and in Deep Bay) and anthropogenic (POM from a local river) nutrient sources were measured, as were those of 22 species of consumers from 20 stations in 4 zones (mangrove forests, inner and outer bay, the estuary) at different distances from the mangroves. While the stable-isotope signatures of the nutrient sources (except the macroalgae Enteromorpha spp.) are sufficiently different to allow their use in tracing trophic relationships, the consumers studied had generally uniform $\delta^{13} \mathrm{C}(\approx-20 \pm 1 \%$ o) and $\delta^{15} \mathrm{~N}\left(\approx+12 \pm 1 \%\right.$ ) signatures. There is, however, a significant increasing trend in the $\delta^{13} \mathrm{C}$ values of consumers at increasing distance from the head of the bay, with the inner-bay consumers having a significantly more negative mean value than their counterparts in the Pearl River estuary. By contrast, $\delta^{15} \mathrm{~N}$ signatures were generally not significantly different among the 3 sampling zones, probably reflecting the similar trophic positions of the species studied. Species that are known to feed at other trophic levels did, however, demonstrate considerable deviations from the overall mean for all consumers. Data from this dual isotope study suggest that the consumer community in Deep Bay and the Pearl River estuary was probably supported mainly by anthropogenic POM input from the local catchment and benthic algae on the mudflat, with a dominance of the latter in the food chains starting from short distances offshore. The results of this study generally agree with the estimations made in a previous mass-balance calculation, which indicated that the contribution from mangrove carbon played a minor trophic role in the system, although the importance of benthic algae as sources of carbon have been under-estimated in the mass-balance calculations. The extensive mudflats in Deep Bay therefore form the basis of not only the feeding habitat for shorebirds utilising the bay as a refueling ground, but also the actual energy source for the system.
\end{abstract}

KEY WORDS: Stable isotopes · Trophodynamics $\cdot$ Mangroves $\cdot$ Mudflat $\cdot$ Benthic algae $\cdot$ Anthropogenic input $\cdot$ Aquatic consumers

Resale or republication not permitted without written consent of the publisher

\section{INTRODUCTION}

The quantitative significance of mangrove organic matter in nearshore food chains has been continuously

\footnotetext{
*Present address: School of Environmental and Applied Sciences, Faculty of Environmental Sciences, Griffith University Gold Coast, PMB 50, Gold Coast Mail Centre, Queensland 9726, Australia. E-mail: joe.lee@mailbox.gu.edu.au
}

debated upon. Early studies on coastal wetlands emphasised the role of mangroves and salt marshes as net exporters of organic matter, a hypothesis largely based on the known high productivity of these communities (Odum 1980). Actual measurements of 'outwelling' from coastal wetlands have yielded equivocal results (e.g. Nixon 1980), with the magnitude, direction and form of organic matter exchange strongly dependent on factors such as the ratio of vegetated to open 
water areas (Dame \& Lefeuvre 1994), the geomorphology of the wetlands (Odum et al. 1979), the tidal regime (Lee 1990, 1995), the activities of macrofauna such as crabs (Robertson 1986, Lee 1989, 1997), and general hydrodynamics of the system (Dame et al. 1986, Wolanski 1995). In general, however, tropical mangrove ecosystems are expected to be net exporters, although the magnitude as well as spatial extent of export appears to be more limited than previously assumed (Lee 1995).

The quantification of mangrove outwelling and its role in nearshore food webs is of increasing concern because of increasing destruction of and urban intrusion into mangroves. Evaluation of the importance of carbon outwelling from mangroves has traditionally followed the mass-balance approach (Lee 1995), which demands a great volume of actual flux and storage measurements, and may yield grossly inaccurate estimates if any significant pathway is omitted (e.g. in situ consumption of leaf litter by sesarmine crabs, Robertson 1986). As an alternative, stable isotopes of carbon, nitrogen and sulphur have increasingly been used as tracers in coastal trophodynamic studies (e.g. Rodelli et al. 1984, Gearing 1988, Fleming et al. 1990, Thomas \& Cahoon 1993, Currin et al. 1995, Newell et al. 1995, Parsons \& Chen 1995). Unlike the conventional massbalance approach, the stable-isotope approach measures actual, time-integrated assimilation of nutrients from potential producers and nutrient sources. There are some problems in data interpretation, such as contribution from multiple sources (Fry \& Sherr 1984), isotopic enrichment across trophic levels (Michener \& Schell 1994), and intra-specific variations in isotopic composition due to site and season (Boon \& Bunn 1994).

The carbon dynamics of Deep Bay, a $112 \mathrm{~km}^{2}$ shallow embayment in the eastern Pearl River estuary, southern China, was examined by Li \& Lee (1998) using the mass-balance approach. The mass-balance model suggested that the available carbon base for the bay, which supports $>68000$ waterfowl every winter, is fundamentally derived from contributions from anthropogenic particulate organic matter (POM) and estuarine phytoplankton sources. The contribution from the fringing mangroves was estimated to account for $<2 \%$ of the total carbon available to consumers. As with all mass-balance studies, assessment of availability does not always clarify patterns of assimilation. Preference and differential digestion by consumers could cause significant discrepancies between the trophic patterns established based on availability (using the mass-balance approach) and actual assimilation (using the stable-isotopes approach). In this study, the carbon source of the bay is independently examined using stable isotopes of carbon and nitrogen in order to ascertain the relative importance of natural versus anthropogenic sources of nutrients in supporting the consumers of this urbanised embayment.

\section{MATERIALS AND METHODS}

Site description. Deep Bay, with an area of $112 \mathrm{~km}^{2}$ (22.41 to $22.53^{\circ} \mathrm{N}, 113.88$ to $114.00^{\circ} \mathrm{E}$ ) is a shallow (average depth $\approx 2.9 \mathrm{~m}$ ) embayment in the eastern Pearl River estuary, southern China. The bay encompasses a large ( $2700 \mathrm{ha}$ ) expanse of intertidal mudflat, fringed by a mangrove community (200 ha) dominated by Kandelia candel, Aegiceras corniculatum and Avicennia marina. The hydrography of the bay is strongly influenced by the discharge from the Pearl River (Motron \& Wu 1975), which is the third largest river in China and has a catchment of about $440000 \mathrm{~km}^{2}$. On a local scale, the bay receives inputs from 2 rivers, the Shan Pui River to the south and the Shenzhen River to the north on the border between Hong Kong and China. The hinterland of Deep Bay, especially the Chinese half, has been extensively developed in the last few decades. Coastal areas on the Hong Kong side comprise a series of land-use features reflecting gradual diminishing tidal influence, from tidal shrimp ponds landward to the mangroves to freshwater fish ponds along the land-sea gradient. Li \& Lee (1998) provided a comprehensive description of the environment of Deep Bay.

Consumer samples for stable-isotope analysis. In September 1993, 21 species of benthic organisms were collected from 20 stations at various distances from the bottom of Deep Bay and extending into the Pearl River estuary (Fig. 1, Table 1). Three groups of stations, differing in their distances from the bottom of the bay, were identified: the inner Deep Bay, outer Deep Bay, and Pearl River estuary stations. The specimens were collected using a commercial Agassiz beam trawl operated at the sampling stations for about $10 \mathrm{~min}$, with a mesh size of $1 \mathrm{~cm}$ at the cod end. The locations of the sampling stations were recorded by a geographic positioning system (GPS). The specimens were put on ice immediately after collection for subsequent stableisotope analysis. Where the same species was collected from more than 1 sampling station in the 3 sampling zones (inner Deep Bay, outer Deep Bay and Pearl River estuary), all individuals collected from the same station were pooled together for analysis, while samples from different stations within the same zone were analysed as separate samples.

Samples of the major potential carbon sources, i.e. the dominant mangroves Kandelia candel, Aegiceras corniculatum and Avicennia marina, the macroalgae 


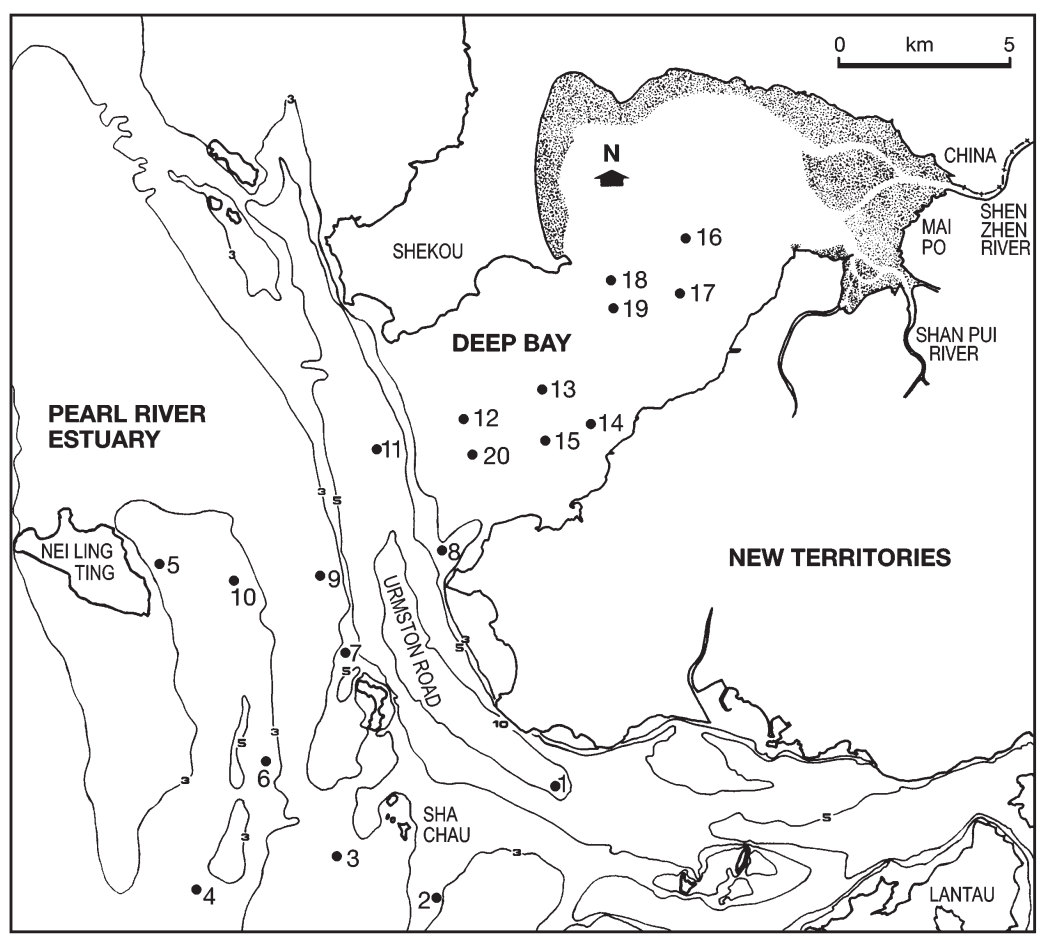

Fig. 1. Deep Bay and eastern Pearl River estuary, showing locations of 20 sampling stations $(\bullet)$ for consumers for stable-isotope analysis. Depth contours are in metres. Locations of the 2 local rivers discharging into Deep Bay are indicated

until samples large enough for isotopic analysis were obtained. Filtered samples were collected in triplicate, whereas organisms (mangroves, algae and consumers) collected from the same station were pooled, homogenised and sub-sampled for stableisotope analysis.

Stable-isotope analysis. The specimens were washed briefly before drying at $80^{\circ} \mathrm{C}$ for $48 \mathrm{~h}$. The dry material was ground in a mortar and sifted through a $100 \mu \mathrm{m}$ mesh to obtain a powder. The material was stored in a desiccator prior to stableisotope analysis. In order to avoid variations in isotopic ratio among different tissues, whole specimens of fish were dried and ground to generate the material for analysis. Only soft tissues were used for analysis in the case of crustaceans. The samples were then processed in the usual ways for stable-isotope analysis. Mass spectrometric measurements of $\mathrm{C}$ and $\mathrm{N}$ were conducted at the facility at the University of Utah, Salt Lake City, USA. The relative abundance of the heavy and light stable isotopes of $\mathrm{C}$

Enteromorpha spp., epipelic mudflat microalgae, seston from mangrove creeks and particulates from major anthropogenic discharge into Deep Bay, were also obtained for analysis. Green as well as senescent, ready-to-fall leaves of the 3 mangroves were hand-picked from the tidal mangrove forest. Samples of the dominant macroalgae, Enteromorpha spp., were obtained from the mudflat and within the tidal shrimp ponds in winter, during their peak season of occurrence (Lee 1990). Seston samples were collected from the mangrove waterways and from the outer Deep Bay and the Pearl River estuary by filtration of large volumes (>5 l) of water samples through pre-combusted Whatman GF-C glass-fibre filters (pore size $\approx 1 \mu \mathrm{m}$ ). Collection along the mangrove creeks was made far from the local discharge points of the anthropogenic particulate sources so as to avoid cross-contamination. Particulates entering into Deep Bay from the local rivers were collected from a branch of the Shan Pui River (Fig. 1) by filter ing water samples through pre-combusted Whatman GF-C filters. Water samples were collected during low tide from the tidal tributary to minimise the influence from material of marine origin. Mudflat epilpelic microalgae were sampled and concentrated using the lens-tissue technique (Eaton \& Moss 1966), and $\mathrm{N}$ are expressed as $\delta^{13} \mathrm{C}$ and $\delta^{15} \mathrm{~N}$ values, with negative values indicating depletion of the heavier isotope relative to a standard reference sample. $\delta^{13} \mathrm{C}$ and $\delta^{15} \mathrm{~N}$ values were calculated according to the following formula:

$$
\delta X(\text { in } \% \text { o })=\left[\left(R_{\text {sample }} / R_{\text {standard }}\right)-1\right] \times 1000
$$

where $X=$ either ${ }^{13} \mathrm{C}$ or ${ }^{15} \mathrm{~N}$; and $R=$ either ${ }^{13} \mathrm{C} /{ }^{12} \mathrm{C}$ or ${ }^{15} \mathrm{~N} /{ }^{14} \mathrm{~N}$ based on a standard of Peedee Belemnite and atmospheric nitrogen, respectively.

The distributions of the $\delta^{13} \mathrm{C}$ and $\delta^{15} \mathrm{~N}$ data obtained are plotted as histograms for 4 groups of stations with varying distances from the mangroves, i.e. within the mangrove forest, inner Deep Bay (Stns 16 to 19), outer Deep Bay (Stns 8, 11 to 15, 20) and the Pearl River estuary (Stns 1 to 7, 9 to 10) (Fig. 1). Dual isotope plots are also generated based on all the data obtained.

The $\delta^{13} \mathrm{C}$ and $\delta^{15} \mathrm{~N}$ values of the various samples collected from the 3 zones were compared using a Kruskal-Wallis non-parametric ANOVA to test if sampling location had an effect on the values. Dunn's multiple-comparison test was applied to cases where significant differences were detected among the 3 zones. 
Table 1. $\delta^{13} \mathrm{C}$ and $\delta^{15} \mathrm{~N}$ of potential sources of nutrient input and of consumers sampled at different locations in Deep Bay and parts of Pearl River estuary. $(\mathrm{n})=$ number of samples of pooled material analysed; where $\mathrm{n} \geq 2$, independent pooled samples were collected from $>1$ station in same zone; mean $( \pm 1 \mathrm{SD})$ values are given where $\mathrm{n} \geq 3$

\begin{tabular}{|c|c|c|c|}
\hline Sample & Location (n) & $\delta^{13} \mathrm{C}(\%)$ & $\delta^{15} \mathrm{~N}(\%)$ \\
\hline \multicolumn{4}{|l|}{ Potential nutrient sources } \\
\hline \multirow[t]{3}{*}{ Kandelia candel } & Tidal mangrove & & \\
\hline & Yellow leaves (1) & -24.36 & 3.98 \\
\hline & Green leaves (2) & -26.56 & 12.56 \\
\hline \multirow[t]{3}{*}{ Avicennia marina } & Tidal mangrove & & \\
\hline & Yellow leaves (1) & -28.08 & 6.07 \\
\hline & Green leaves (1) & -27.31 & 12.34 \\
\hline Aegiceras corniculatum & Yellow leaves (1) & -28.05 & 6.58 \\
\hline Enteromorpha spp. & Mudflat (5) & $-21.07 \pm 2.62$ & $3.67 \pm 6.81$ \\
\hline Seston & Mangrove creek (4) & $-27.16 \pm 0.44$ & $10.48 \pm 0.21$ \\
\hline Seston & Pearl River estuary (6) & $-25.22 \pm 0.48$ & $-1.06 \pm 0.98$ \\
\hline POM & Shan Pui River (2) & -24.13 & 5.23 \\
\hline Microalgae & Intertidal mudflat (3) & $-19.27 \pm 0.06$ & $-0.20 \pm 0.04$ \\
\hline \multicolumn{4}{|l|}{ Consumers } \\
\hline \multicolumn{4}{|l|}{ Crustaceans } \\
\hline \multicolumn{4}{|l|}{ Grapsidae } \\
\hline Perisesarma bidens & Tidal mangrove (4) & -24.20 & 6.70 \\
\hline \multirow{2}{*}{\multicolumn{4}{|c|}{ Palaemonidae }} \\
\hline & & & \\
\hline Exopalaemon styliferus & Inner bay (1) & -20.76 & 9.44 \\
\hline \multicolumn{4}{|l|}{ Penaeidae } \\
\hline \multirow[t]{2}{*}{ Metapenaeus ensis } & Inner bay (1) & -20.16 & 12.05 \\
\hline & Outer bay (4) & -19.96 & $12.21 \pm 0.72$ \\
\hline \multirow[t]{2}{*}{ M. affinis } & Inner bay (1) & -20.11 & 11.79 \\
\hline & Outer bay (1) & -20.11 & 12.60 \\
\hline \multirow{2}{*}{ Parapeneopsis hungerfordi } & Inner bay (2) & -20.06 & 12.14 \\
\hline & Outer bay (1) & -20.11 & 12.28 \\
\hline \multicolumn{4}{|l|}{ Portunidae } \\
\hline \multirow[t]{2}{*}{ Charybdis japonicus } & Inner bay (2) & -20.57 & 12.60 \\
\hline & Outer bay (5) & $-21.96 \pm 2.47$ & $14.53 \pm 0.79$ \\
\hline Stomatopoda & & & \\
\hline Harpiosquilla sp. & Inner bay (3) & $-20.23 \pm 0.19$ & $12.43 \pm 0.60$ \\
\hline & Outer bay (3) & $-19.89 \pm 0.08$ & $9.99 \pm 3.17$ \\
\hline & Estuary (7) & $-19.63 \pm 0.92$ & $11.83 \pm 0.48$ \\
\hline Oratosquilla sp. 1 & Inner bay (3) & $-20.13 \pm 0.18$ & $12.40 \pm 0.60$ \\
\hline & Outer bay (4) & $-20.27 \pm 0.10$ & $11.75 \pm 0.07$ \\
\hline & Estuary (3) & $-19.85 \pm 0.35$ & $12.07 \pm 1.62$ \\
\hline Oratosquilla sp. 2 & Inner bay (2) & -20.44 & 12.39 \\
\hline & Outer bay (3) & $-19.57 \pm 0.85$ & $11.61 \pm 1.41$ \\
\hline & Estuary (6) & $-19.12 \pm 0.90$ & $11.72 \pm 0.44$ \\
\hline Stomatopod sp. D & Estuary (3) & $-18.15 \pm 0.68$ & $12.36 \pm 0.40$ \\
\hline Stomatopod sp. E & Estuary (1) & -18.15 & 10.445 \\
\hline Pisces & & & \\
\hline Taenioididae & & & \\
\hline Odontamblyopus rubicundus & Outer bay (1) & -20.08 & 11.26 \\
\hline Eleotridae & & & \\
\hline Butis butis & Estuary (2) & -19.55 & 11.48 \\
\hline Polynemidae & & & \\
\hline Eleutheronema tetradactylus & Inner bay (1) & -20.87 & 12.73 \\
\hline & Outer bay (1) & -20.09 & 14.78 \\
\hline & Estuary (1) & -20.33 & 11.95 \\
\hline Paralichthyidae & & & \\
\hline Tephrinectes sinensis & Inner bay (1) & -20.69 & 11.91 \\
\hline & Outer bay (1) & -20.35 & 12.58 \\
\hline & Estuary (1) & -18.8 & 11.37 \\
\hline Sciaenidae & & & \\
\hline Johnius fasciatus & Inner (1) & -21.07 & 13.56 \\
\hline & Estuary (1) & -18.32 & 13.03 \\
\hline Ambassidae & & & \\
\hline Ambassis gymnocephalus & Inner bay (1) & -20.78 & 10.48 \\
\hline Engraulidae & & & \\
\hline Coilia mystus & Inner bay (2) & -20.23 & 10.93 \\
\hline & Outer bay (1) & -19.53 & 11.26 \\
\hline & Estuary (1) & -20.89 & 12.22 \\
\hline Syngnathidae & & & \\
\hline Syngnathus acus & Inner bay (1) & -19.82 & 11.19 \\
\hline Lutjanidae & & & \\
\hline Lutjanus monostigma & Outer bay (1) & -20.10 & 12.94 \\
\hline
\end{tabular}




\section{RESULTS}

\section{Stable-isotope ratio of potential nutrient sources}

The use of dual isotopes of $\mathrm{C}$ and $\mathrm{N}$ facilitated the identification of the respective potential nutrient sources within Deep Bay. The yellow leaves of 2 mangrove species had characteristically highly negative $\delta^{13} \mathrm{C}\left(>-28 \%\right.$ o) but relatively low $\delta^{15} \mathrm{~N}(\approx 6 \%$ o) values (Table 1). The macroalgae Enteromorpha spp. had rather low average $\delta^{13} \mathrm{C}$ but high $\delta^{15} \mathrm{~N}$ values, and samples collected at different time had different signatures. Two samples collected in September had more negative $\delta^{13} \mathrm{C}\left(-24 \%\right.$ ) but positive $\delta^{15} \mathrm{~N}$ (average $11.3 \%$ ), whereas the corresponding values for the samples collected in March were -19 and $-1 \%$. Seston from the mangrove creeks had $\delta^{15} \mathrm{~N}$ values similar to Enteromorpha spp. but had a $\delta^{13} \mathrm{C}$ signature close to that of the senescent mangrove leaves. Particulate matter from Shan Pui River had more positive $\delta^{13} \mathrm{C}$ values $(-24 \%$ ) compared to the macrophyte carbon sources and the seston in Deep Bay. Enteromorpha spp. and benthic microalgae on the mudflat had the most positive $\delta^{13} \mathrm{C}$ values (average $\approx-21.1$ and $-19 \%$, respectively). The benthic microalgae also had highly negative $\delta^{15} \mathrm{~N}$ values $(\approx-1 \%$ ), while the range for Enteromorpha spp. was large ( -1 to $+14 \%$, average $\approx 3.7 \%$ ). These potential nutrient sources can thus be readily identified using the dual isotope approach (Table 1, Fig. 2). Interpretation of the contribution from Enteromorpha spp. is, however, more difficult as the signature is significantly more variable.

\section{Stable-isotope ratio of consumers}

Most of the consumers for which isotopic composition was measured were low-level omnivores or predators. The two sesarmine crabs Perisesarma bidens and Parasesarma affinis are consumers of detritus and other sediment organic matter. This feeding habit of the crabs was well distinguished from that of the other consumers by the isotopic ratios (Table 1). The crabs had almost identical $\delta^{13} \mathrm{C}\left(\approx-24 \%\right.$ ) and $\delta^{15} \mathrm{~N}(\approx 6$ to $7 \%$ o) values which, when adjusted for isotopic fractionation for $\mathrm{N}$ (assuming $+3.3 \%$ per trophic level: Michener $\&$ Schell 1994), were collectively indicative of a diet based on either particulates from the local catchments, e.g. the Shan Pui River particulates (Table 1) or pure Kandelia candel detritus, but not mixed mangrove detritus (mean $\delta^{13} \mathrm{C}=-26.83 \%$ ).

The values of $\delta^{13} \mathrm{C}$ and $\delta^{15} \mathrm{~N}$ of the other consumers varied within narrow ranges for the taxa measured. The crustacean groups of Palaemonidae, Penaeidae and Stomatopoda had $\delta^{13} \mathrm{C}$ values close to $-20 \%$, with an average of $-19.96 \pm 0.81 \%$ o $(\mathrm{n}=20)$ for all the crustacean samples measured. Their $\delta^{15} \mathrm{~N}$ values also varied within narrow limits, with most values close to $12 \%$ (mean $=11.93 \pm 1.04 \%$ o, $\mathrm{n}=20)$. Significant deviations ( $>1 \%$ difference) from the group average were recorded for 2 mantis shrimp samples for $\delta^{13} \mathrm{C}$ and for 2 samples of mantis shrimps, Exopalaemon styliferus, and 1 sample of Charybdis japonicus for $\delta^{15} \mathrm{~N}$.

A similar picture was apparent for the fish species. Again, most species sampled were first- or secondlevel predators. Most species had $\delta^{13} \mathrm{C}$ and $\delta^{15} \mathrm{~N}$ values close to -20 and $12 \%$, respectively. The mean values $( \pm \mathrm{SD})$ for the 16 samples analysed were $-20.09 \pm 0.74$ and $12.10 \pm 1.08 \%$ for $\delta^{13} \mathrm{C}$ and $\delta^{15} \mathrm{~N}$, respectively. Two species, Ambassis gymnocephalus and Coilia mystus, demonstrated significantly lower than average $(<11 \%$ ) values, whereas Johnius fasciatus, Eleutheronema tetradactylus and Lutjanus monostigma had generally higher than average (mean $\geq 13 \%$ ) $\delta^{15} \mathrm{~N}$ values within the fish group.

\section{Longitudinal trend from Deep Bay}

Of the 12 samples obtained and analysed for $\delta^{13} \mathrm{C}$ in $\geq 2$ zones, 7 show an increase, 2 a decrease, 1 no change and 2 no obvious trends in values going from inner Deep Bay to either outer bay or the Pearl River estuary (Table 1). The same trend was apparent when

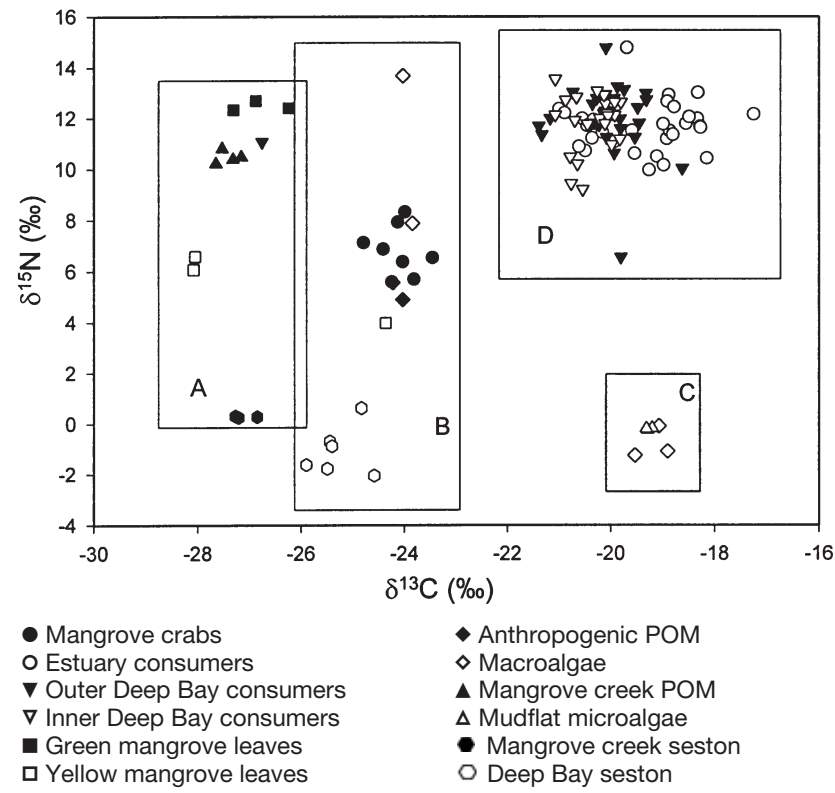

Fig. 2. Dual isotope plot of the $\delta^{15} \mathrm{~N}$ and $\delta^{13} \mathrm{C}$ values for all samples analysed, revealing 3 groups of data points for carbon sources: (A), mangrove, (B) anthropogenic POM, (C) benthic algae sources; (D) signatures of consumers in the 4 regions of mangrove system 
Table 2. Changes in average $\delta^{13} \mathrm{C}$ and $\delta^{15} \mathrm{~N}$ values recorded for consumers from inner Deep Bay (DB), outer Deep Bay and Pearl River estuary sampling zones. Since values for different species varied within narrow ranges, data collected for all species from a particular zone were pooled for comparison with the other zones. In most cases, each individual data point represents a pooled sample from a large number of individuals. Results of Kruskal-Wallis non-parametric ANOVA and 1-way ANOVA are shown, respectively, for the $\delta^{13} \mathrm{C}$ and $\delta^{15} \mathrm{~N}$ comparisons for effect of collection zone on the values. Superscripts indicate results of Dunn's multiple-comparison test $(H)$ on $\delta^{13} \mathrm{C}$ data: values sharing same superscript are not significantly different from each other at $\mathrm{p}=0.05$

\begin{tabular}{|lccc|}
\hline Zone & $\begin{array}{c}\text { Mean }( \pm 1 \mathrm{SD}) \\
(\%)\end{array}$ & $H$ or $F$ & $\mathrm{p}$ \\
\hline $\boldsymbol{\delta}^{\mathbf{1 3}} \mathbf{C}$ & & & \\
Inner DB & $-20.42 \pm 0.36^{\mathrm{a}}$ & 11.7 & 0.0028 \\
Outer DB & $-20.16 \pm 0.59^{\mathrm{a}, \mathrm{b}}$ & & \\
Pearl River & $-19.28 \pm 0.89^{\mathrm{b}}$ & & \\
$\boldsymbol{\delta}^{\mathbf{1 5}} \mathbf{N}$ & & & \\
Inner DB & $11.85 \pm 1.03$ & 0.733 & 0.488 \\
Outer DB & $12.32 \pm 1.29$ & & \\
Pearl River & $11.85 \pm 0.65$ & & \\
\hline
\end{tabular}

the data from all consumers were pooled for the 3 zones (Table 2), with the mean $\delta^{13} \mathrm{C}$ for inner Deep Bay species being $1.14 \%$ more negative than their counterparts in the Pearl River estuary stations. ANOVA on the values recorded for the 3 zones using pooled data suggests a significant difference in $\delta^{13} \mathrm{C}$ with respect to sampling zone (Kruskal-Wallis ANOVA on ranks, $H=$ 11.7, $\mathrm{df}=2, \mathrm{p}=0.0028$ ), with the inner Deep Bay samples having significantly different values from the estuary samples (Dunn's test: $Q=3.41, \mathrm{p}<0.05$ ). There was, however, no significant difference in the $\delta^{15} \mathrm{~N}$ values among the 3 zones (ANOVA: $F=0.733$, df $=2$, $\mathrm{p}=0.488$; Table 2).

\section{DISCUSSION}

\section{Stable-isotope ratio values of potential carbon sources}

The $\delta^{13} \mathrm{C}$ and $\delta^{15} \mathrm{~N}$ values obtained for the primary producers and anthropogenic input generally agree with those recorded by previous studies. Mangroves usually have highly negative $\delta^{13} \mathrm{C}$ values, typically at $<-27 \%$ (Rodelli et al. 1984, Rezende et al. 1990, Newell et al. 1995). Currin et al. (1995) compiled a large data base on the recorded $\delta^{13} \mathrm{C}$ and $\delta^{15} \mathrm{~N}$ for benthic macroalgae, calculating a mean $\delta^{13} \mathrm{C}$ of $-16.6 \pm 5.8$ (SE) \% for the group, including a value of $-9.6 \%$ for Enteromorpha spp. from Nova Scotia. These values are considerably more positive than those recorded for Enteromorpha spp. in the present study. The large range was also echoed by Newell et al. (1995), who also recorded a wide range of values (between -19.94 and $-36.45 \%$ ) $\delta^{13} \mathrm{C}$ for the 4 macroalgae species they investigated. The $\delta^{15} \mathrm{~N}$ values were, however, similar in both studies $(\approx+11 \%$ ). High variability was also recorded for the macroalgae samples in this study ( -24 to $-19 \%$ for $\delta^{13} \mathrm{C}$ and -1 to $14 \%$ for $\delta^{15} \mathrm{~N}$ ). Boon \& Bunn (1994) reported wide ( $>10 \%$ in some cases) intra-specific variations in the carbon and nitrogen isotopic signatures arising from site and season differences and warned against direct extrapolation of data across sites. While such inherent variability of the values legitimately warrants caution in data interpretation, it is unlikely that full appreciation of the variability will be achieved in the near future, as data from many habitat regimes and potential producers (e.g. bacteria) are still generally scarce. In the present study, the large variation in the signature for Enteromorpha spp. makes assessment of the contribution from this source difficult.

The seston samples in the present study displayed a unique combination of $\delta^{13} \mathrm{C}$ and $\delta^{15} \mathrm{~N}$ values. Seston samples collected from the local creeks and from the Pearl River estuary had distinctly different signatures, especially in terms of $\delta^{15} \mathrm{~N}$ (Table 1), suggesting contribution from different sources. The high positive $\delta^{15} \mathrm{~N}$ of seston in the mangrove creek probably reflects the abundance of mangrove detritus and anthropogenic POM (all with highly positive $\delta^{15} \mathrm{~N}$ ), whereas the estuarine seston was more likely dominated by phytoplankton. It is expected that these samples represented mixtures of detrital material, plankton, and anthropogenic material. This is possible, as no special control (which would be difficult) was made on the inclusion or exclusion of the various potential materials present in the mangrove creek water or in the estuary. In contrast, collection of the sample representing input from local catchments (the POM sample from Shan Pui River) was made specifically to include riverine material. The values recorded for the POM from Shan Pui River are suggestive of significant anthropogenic origin rather than of terrestrial primary producers. Most terrestrial plants are $\mathrm{C}_{3}$ plants and have a mean $\delta^{13} \mathrm{C}$ value of $\leq-27 \%$ and $\delta^{15} \mathrm{~N}$ of $<+2 \%$ (Boutton 1991, Coffin et al. 1994, Nadelhoffer \& Fry 1994). The C and $\mathrm{N}$ stable-isotope signatures of domestic sewage have not been well documented, but the available reports suggest values for $\delta^{13} \mathrm{C}$ of about -23 to $-28 \%$ and $\delta^{15} \mathrm{~N}$ at $\approx+2 \%$ o (Burnett \& Schaeffer 1980, Coffin et al. 1994, Thornton \& McManus 1994, Andrews et al. 1998). Although the present values obtained $\left(\delta^{13} \mathrm{C}\right.$ at $\approx-24 \%$ and $\delta^{15} \mathrm{~N}$ at $\approx+5 \%$ ) for the POM from Shan Pui River do not correspond exactly with these published ranges, anthropogenic organic enrichment in the discharge is undoubtedly the main $\mathrm{C}$ and $\mathrm{N}$ sources along the river. Regular monitoring of water 
quality of Shan Pui River, and its equivalent in the northern end of Deep Bay, the Shenzhen River, suggest gross organic enrichment (EPD 1995). BOD 5 levels were $\geq 50 \mathrm{mg} \mathrm{l}^{-1}$ for the tributaries of Shenzhen River, and $125 \mathrm{mg} \mathrm{l}^{-1}$ for Shan Pui River in 1988 (EPD 1989).

The isotopic ratio for the epipelic microalgae on the inner Deep Bay mudflat also allows this group to be distinguished from the other carbon sources. This carbon source is characterised by less negative $\delta^{13} \mathrm{C}$ $\left(\approx-19 \%\right.$ ) but very low $\delta^{15} \mathrm{~N}$ values $(\approx-1 \%$ o). Estimates of the isotopic signatures of benthic microalgae are few, but the values (especially of $\delta^{15} \mathrm{~N}$ ) obtained in this study agree well with those reported for the same group by Currin et al. (1995) and France $(1995,1998)$.

\section{Potential sources of nutrients for consumers in Deep Bay and Pearl River estuary}

Since a number of potential nutrient sources are present in Deep Bay, no attempt has been made here to estimate the relative contribution of these sources (see Harrigan et al. 1989 and Gearing 1991 on the limitations of mixing equations). There are, however, a few observations that can be made based on the stable isotope data.

Qualitative examination of the stable-isotope ratios of the carbon sources and of the consumers in Deep Bay suggests little contribution from mangrove sources (Fig. 2). Although mangrove leaf litter and POM from Shan Pui River have similar average $\delta^{15} \mathrm{~N}$ values (5.54 and $5.23 \%$, respectively), their $\delta^{13} \mathrm{C}$ values are considerably different $(-26.83$ and $-24.13 \%$, respectively). Mangrove litter probably made up a significant portion of the seston in the mangrove creek, but correspondence between its $\delta^{13} \mathrm{C}$ signature and those of the consumers was weak (Figs. 2 \& 3). While the apparent ratios of the consumers could still be a result of combined contributions from the mangroves and other sources with much more positive signatures, the large difference between the signatures of the mangroves and of the consumers questions this possibility. In contrast, significant influence from anthropogenic POM, estuarine seston and benthic algae is likely. Consumers collected from Deep Bay and the Pearl River estuary have consistent and narrow ranges for both carbon and nitrogen isotopic signatures $(-20 \pm 1$ and $+12 \pm 1 \%$, respectively). This consistency suggests that probably the consumer assemblage was utilising a common carbon source(s), while similar trophic positions of the consumers also resulted in a conservative range of $\delta^{15} \mathrm{~N}$. The contribution from the benthic macro- and microalgae deserves particular attention, as this is the only carbon source with an average $\delta^{13} \mathrm{C}$ signature almost identical to those of the consumers

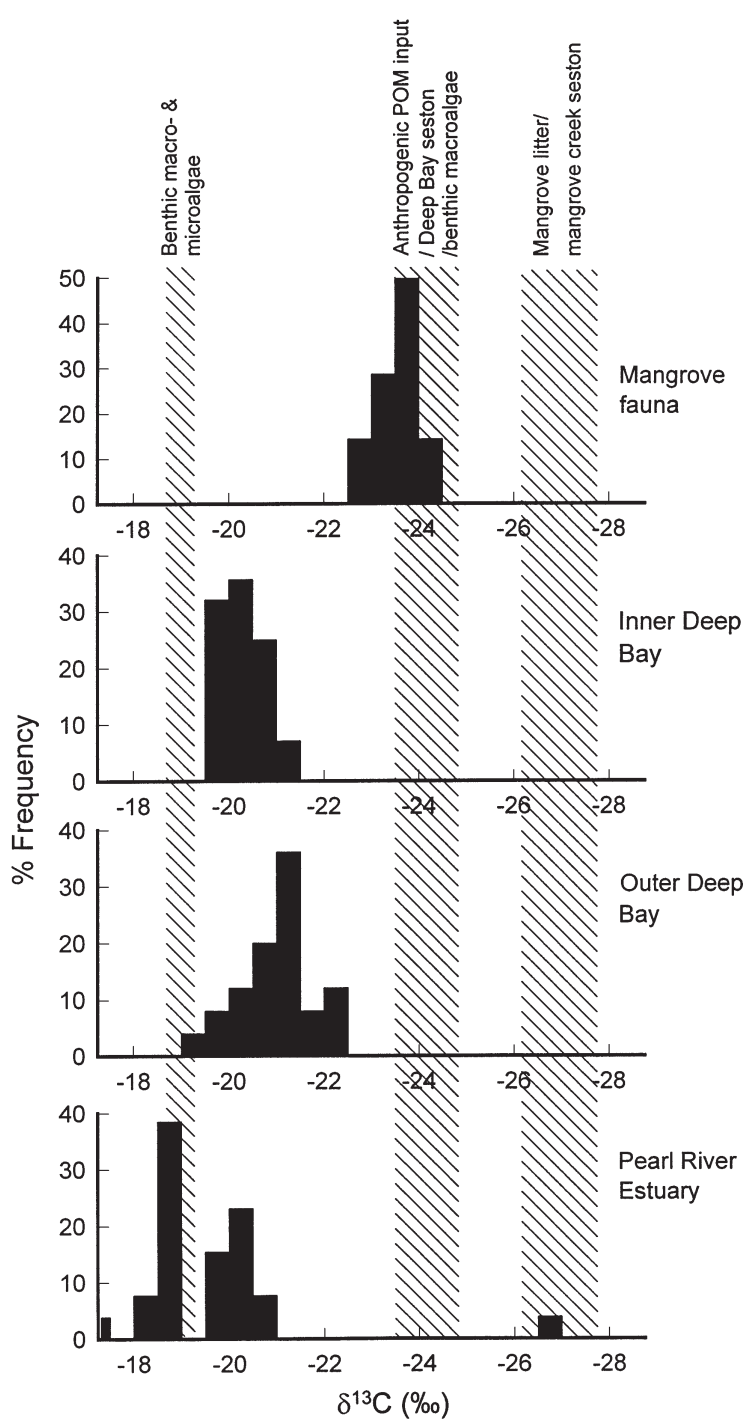

Fig. 3. $\delta^{13} \mathrm{C}$ of consumers collected from the 4 sampling zones. Range measured for important potential carbon sources are indicated for comparison

sampled. Further, these are the only 2 sources with the least negative $\delta^{13} \mathrm{C}$ values, mirroring those of the consumers. Unless additional sources with even more positive $\delta^{13} \mathrm{C}$ values were present, the contribution from the other measured sources should be small, since mixtures of the present complement of carbon sources will not be able to produce consumer signatures heavier than about $-21 \%$. Past studies on trophodynamics in estuarine ecosystems have focussed on the contribution of macrophytes, probably because of their easy discernment. Microscopic producers, such as benthic microalgae and bacteria, have largely been ignored. The contribution from these microscopic sources deserves more attention, as the high turnover rate of their production may more than compensate for the low standing-crop biomass. Similar to the findings 
of this report, Newell et al. (1995) demonstrated that benthic microalgae were the main suppliers of carbon on Malaysian intertidal mudflats.

The sesarmine crabs Perisesarma bidens and Parasesarma affinis have been demonstrated to be the major consumers of mangrove leaf litter in the tidal shrimp ponds in inner Deep Bay (Lee 1989, 1990). Individuals in the tidal mangroves have, however, carbon signatures (average $-24.11 \%$ ) probably indicative of a significant reliance on POM input from the local catchment $(-24.13 \%)$ but not mangrove detritus (average $-26.83 \%$ ). These crabs spend significant amounts of time picking up surface mud from the forest floor and may, in the process, tap the benthic microalgal as well as POM input from non-mangrove sources.

In the majority of cases, there is an increasing trend in the $\delta^{13} \mathrm{C}$ of the same species for samples obtained at increasing distance from inner Deep Bay (Table 2). A significant difference was also detected between the $\delta^{13} \mathrm{C}$ values of the pooled consumer data with increasing distance from the head of Deep Bay. This gradual increase toward positive $\delta^{13} \mathrm{C}$ values suggests that there is a shift in the primary carbon source. The nature of this shift is, however, uncertain. Based on the stable-isotope signatures of the most likely carbon sources (anthropogenic POM, estuarine seston and benthic algae), the shift seems to arise from a gradual change from dependence on a mixture of these sources to increasing dependence on the benthic algae, in the direction of the Pearl River estuary. Heavier dependence of the inner Deep Bay consumers on anthropogenic POM and estuarine seston is possible, as has been suggested by a parallel assessment of the carbon availability of Deep Bay using the conventional massbalance approach (Li \& Lee 1998). These authors concluded, from calculations based on the input of organic carbon from various sources, that the fringing mangroves only contribute $<2 \%$ of all available carbon, whereas phytoplankton and anthropogenic input each accounts for about half the overall carbon supply. The results of the mass-balance study suggest that Deep Bay, being an estuarine embayment with significant urbanisation in its hinterland, is a system maintained in part by substantial anthropogenic sources of nutrients. Currently, the mudflats in inner Deep Bay support $>68000$, mostly migratory, waterfowl every winter (Hong Kong Bird Watching Society 1995). The lack of significant contribution from the 200 ha of fringing mangroves is also demonstrated by the dual isotope plots in Fig. 2.

The present study also suggests small significance of the contribution from the mangroves, and highlights the potential importance of primary production on the expansive mudflat. This is not surprising in view of the overwhelming abundance of organic enrichment from the local catchment compared with the limited area of the mangroves in Deep Bay. The mudflats are probably the key habitat in this system, offering not only the potential major source of carbon, but also the physical habitat for this production to be tapped by the target conservation species, i.e. the migratory shorebirds.

It is nevertheless unclear why the signatures of consumers in the Pearl River estuary should bear strong affiliation to the signatures of benthic algal producers on the mudflat. One possibility is that the consumers in Deep Bay are dependent on phytoplankton and benthic algae that derive their nutrients from anthropogenic input. As with the mass-balance approach, failure to account for the presence of important carbon sources in the measurements or calculations could lead to a false picture of the relative significance or wrong conclusions regarding the sources of assimilated carbon. This question will probably be clarified only through further detailed studies of the biology of foodweb relationships in the system. A significant trophic role, which has often been assumed for all mangroves, is not applicable to this human-impacted embayment. It is expected that the mangroves themselves may serve the role of stripping nutrients and organic matter from the water, but this and the other potential roles of urbanised mangroves have to be further ascertained.

The $\delta^{15} \mathrm{~N}$ values of the consumers are in good agreement with the pattern expected as a result of isotopic fractionation across trophic levels. Peterson \& Fry (1987) reviewed the change in isotopic signatures upon assimilation of food by consumers and concluded that there is, on average, a change of about $+3.3 \%$ in $\delta^{15} \mathrm{~N}$ per trophic level. The consumers measured in the present study were mostly low level predators at Trophic Levels 2 and 3. Assuming a 3.3\% shift per trophic level, these consumers are probably supported by a $\mathrm{N}$ source with a $\delta^{15} \mathrm{~N}$ of $(12-2 \times 3.3)=5.4 \%$ or $(12-3 \times 3.3)=2.1 \%$, which is largely in agreement with that measured for the local anthropogenic POM input $(5.23 \%)$ (2 steps) or the microalgae/estuarine seston (0 to $-1 \%$; 3 steps) (Fig. 4). This provides further support to the conclusion drawn from the carbonisotope data. There is also the possibility of support from the macroalgae (C: Fig. 2) but the large variability amongst samples makes this interpretation uncertain.

\section{Implications for Deep Bay}

The trophic role of mangroves, with their other beneficial roles as proposed nursery site and protective barriers of the shoreline, is a strong argument for their conservation. While large-scale mangrove destruction is a real concern, the results of this study and those of Li \& Lee (1998) suggest that the actual trophic role of 


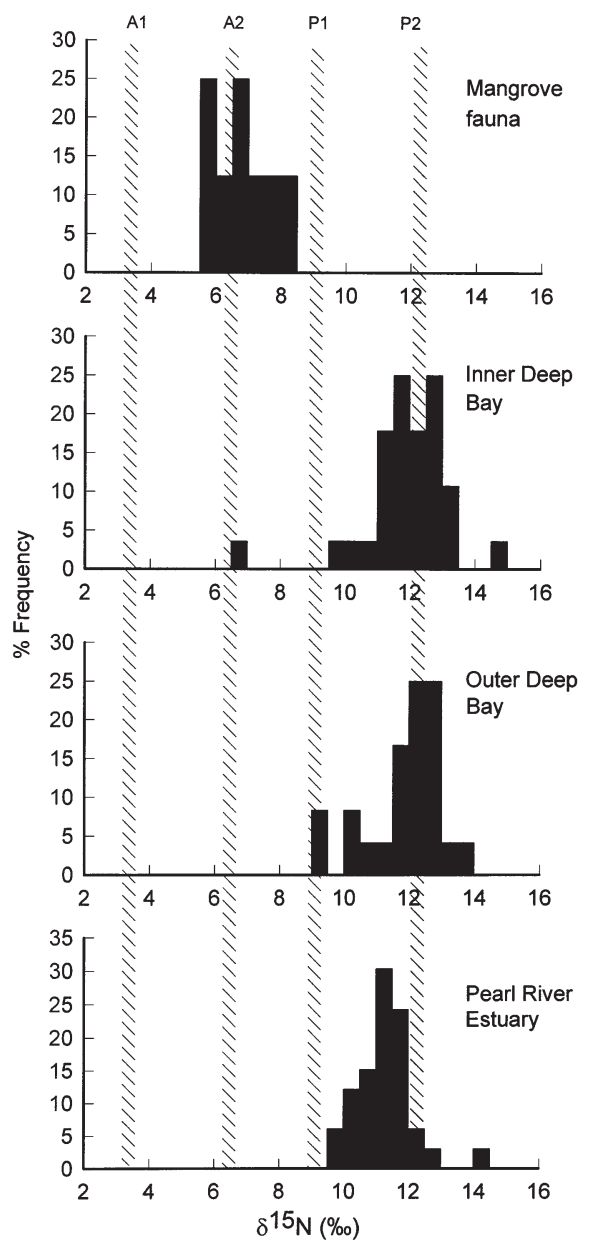

Fig. 4. $\delta^{15} \mathrm{~N}$ of consumers collected from the 4 sampling zones. Since $\delta^{15} \mathrm{~N}$ is more affected than $\delta^{13}$ by the trophic position of the consumers, expected location of $\delta^{15} \mathrm{~N}$ signatures of primary and secondary consumers based on anthropogenic POM (P1, P2 respectively) and benthic algae (A1, A2 respectively) are indicated

mangroves in human-impacted settings has to be reassessed in the light of the anthropogenic disturbance on wetland-dominated systems. The importance of human interference such as habitat destruction and, increasingly, discharge of nutrients, in coastal areas cannot be dismissed in any analysis of such systems. Although both studies indicate a small trophic contribution by the mangroves, there are some discrepancies between the situation as suggested by the massbalance study (Li \& Lee 1998) and that reflected by the present stable-isotope study. The mass-balance study suggested a dominance of anthropogenic POM in the available carbon pool in inner Deep Bay whereas phytoplankton was expected to be the major source of carbon in the estuary. Although this broad picture was largely confirmed by this study, the significance of benthic algae on the mudflats was neglected in the mass-balance calculations. The discrepancies probably reflect (1) the different parameters (availability versus assimilation) measured in the 2 approaches; and (2) the general lack of information on the productivity of microalgae on intertidal mudflat systems. Such deficiencies should be addressed in future studies on the trophic ecology of estuarine ecosystems.

Acknowledgements. I thank Drs S. F. Leung and Richard Cheung for their cheerful company and help in benthos sampling and Sandy Kwok for general help in field and laboratory work. Dr Guanghui Lin not only helped with the stableisotope analysis but also provided useful advice for the work. The trawl sampling programme was supported by a grant from the Vice-Chancellor of the University of Hong Kong. This work is supported by Grant 295/92M from the Research Grants Council, Hong Kong.

\section{LITERATURE CITED}

Andrews JE, Greenaway AM, Dennis PF (1998) Combined carbon isotope and $\mathrm{C} / \mathrm{N}$ ratios as indicators of source and fate of organic matter in a poorly flushed, tropical estuary: Hunts Bay, Kingston Harbour, Jamaica. Estuar Coast Shelf Sci 46:743-756

Boon PI, Bunn SE (1994) Variations in the stable isotope composition of aquatic plants and their implications for food web analysis. Aquat Bot 48:99-108

Boutton TW (1991) Stable isotope ratios of natural materials: II. Atmospheric, terrrestrial, marine, and freshwater environments. In: Coleman DC, Fry B (eds) Carbon isotope techniques, Academic Press, New York, p 173-185

Burnett WC, Schaeffer OA (1980) Effect of ocean dumping of ${ }^{13} \mathrm{C} /{ }^{12} \mathrm{C}$ ratios in marine sediments from the New York Bight. Estuar Coast Shelf Sci 11:605-611

Coffin RB, Cifuentes LA, Elderidge PM (1994) The use of stable carbon isotopes to study microbial processes in estuaries. In: Lajtha K, Michener RH (eds) Stable isotopes in ecology and environmental science. Blackwell Scientific Publications, Oxford, p 222-240

Currin CA, Newell SY, Paerl HW (1995) The role of standing dead Spartina alterniflora and benthic microalgae in salt marsh food webs: considerations based on multiple stable isotope analysis. Mar Ecol Prog Ser 121:99-116

Dame R, Chrzanowski T, Bildstein K, Kjerve B, McKellar H, Nelson D, Spurrier J, Satncyk S, Stevenson H, Vernberg J, Zingmark R (1986) The outwelling hypothesis and North Inlet, South Carolina. Mar Ecol Prog Ser 33:217-229

Dame R, Lefeuvre JC (1994) Tidal exchange: import-export of nutrients and organic matter in new and old world salt marshes: conclusions. In: Mitsch WJ (ed) Global wetlands: old world and new. Elsevier Science BV, Amsterdam, p 303-305

Eaton JM, Moss B (1966) The estimation of numbers and pigment content in epipelic algal populations. Limnol Oceanogr 11:584-595

EPD (1989) River water quality in Hong Kong. Environmental Protection Department, Hong Kong Government, Hong Kong

EPD (1995) Marine water quality in Hong Kong. Environmental Protection Department, Hong Kong Government, Hong Kong

Fleming M, Lin G, da Silveira Lobo, Sternberg L (1990) In- 
fluence of mangrove detritus in an estuarine ecosystem. Bull Mar Sci 47:663-669

France RL (1995) Carbon-13 enrichment in benthic compared to planktonic algae: foodweb implications. Mar Ecol Prog Ser 124:307-312

France RL (1998) Estimating the assimilation of mangrove detritus by fiddler crabs in Laguna Joyunda, Puerto Rico, using dual stable isotopes. J Trop Ecol 14:413-425

Fry B, Sherr EB (1984) $\delta^{13} \mathrm{C}$ measurements as indicators of carbon flow in marine and freshwater ecosystems. Contrib Mar Sci 27:13-47

Gearing JN (1988) The use of stable isotope ratios for tracing the nearshore-offshore exchange of organic matter. In: Jansson BO (ed) Coastal-offshore ecosystem interactions. Springer Verlag, Berlin, p 69-101

Gearing JN (1991) The study of diet and trophic relationships through natural abundance of ${ }^{13} \mathrm{C}$. In: Coleman DC, Fry B (eds) Carbon isotope techniques. Academic Press, New York, p 201-218

Harrigan P, Zieman JC, Macko SA (1989) The base of nutritional support for the gray snapper (Lutjanus griseus): an evaluation based on a combined stomach content and stable isotope analysis. Bull Mar Sci 44:65-77

Hong Kong Bird Watching Society (1995) Hong Kong bird report. World Wide Fund for Nature Hong Kong, Hong Kong

Lee SY (1989) The importance of inundation frequency and Sesarminae crabs on the decomposition of mangrove (Kandelia candel [L.] Druce) litter in a Hong Kong tidal shrimp pond. J Exp Mar Biol Ecol 130:23-43

Lee SY (1990) Primary productivity and particulate organic matter flow in an estuarine mangrove-wetland in Hong Kong. Mar Biol 106:453-463

Lee SY (1995) Mangrove outwelling: a review. Hydrobiologia 295:203-212

Lee SY (1997) Potential trophic importance of the faecal material of the mangrove sesarmine crab Sesarma messa. Mar Ecol Prog Ser 159:275-284

Li MS, Lee SY (1998) Carbon dynamics of Deep Bay, eastern Pearl River estuary, China. I: A mass balance budget and implications for shorebird conservation. Mar Ecol Prog Ser 172:73-87

Michener RH, Schell DM (1994) Stable isotope ratios as tracers in marine aquatic food webs. In: Lajtha $\mathrm{K}$, Michener $\mathrm{RH}$ (eds) Stable isotopes in ecology and environmental science. Blackwell Scientific Publications, Oxford, p 138-157

Motron B, Wu RSS (1975) The hydrology of the coastal waters of Hong Kong. Environ Res 10:319-347

Nadelhoffer KJ, Fry B (1994) Nitrogen isotope studies in forest

Editorial responsibility: Otto Kinne (Editor),

Oldendorf/Luhe, Germany ecosystems. In: Lajtha K, Michener RH (eds) Stable isotopes in ecology and environmental science. Blackwell Scientific Publications, Oxford, p 22-44

Newell RIE, Marshall N, Sasekumar A, Chong VC (1995) Relative importance of benthic algae, phytoplankton, and mangroves as sources of nutrition for penaeid prawns and other coastal invertebrates from Malaysia. Mar Biol 123: $595-606$

Nixon SW (1980) Between coastal marshes and coastal waters - a review of twenty years of speculation and research on the role of salt marshes in estuarine productivity and water chemistry. In: Hamilton P, MacDonald KB (eds) Estuarine and wetland processes. Plenum Press, New York, p 437-525

Odum EP (1980) The status of three ecosystem-level hypotheses: outwelling, tidal subsidy and detritus-based food chain. In: Kennedy VS (ed) Estuarine perspectives. Academic Press, New York, p 69-80

Odum WE, Fisher JS, Prickal JC (1979) Factors controlling the flux of particulate organic carbon from wetlands. In: Livingston RJ (ed) Ecological processes in coastal and marine systems. Plenum Press, New York, p 69-80

Parsons TR, Chen YLL (1995) The comparative ecology of a subarctic and tropical estuarine ecosystem as measured with carbon and nitrogen isotopes. Estuar Coast Shelf Sci 41:215-224

Peterson BJ, Fry B (1987) Stable isotopes in ecosystem studies. Annu Rev Ecol Syst 18:293-320

Rezende CE, Lacerda LD, Ovalle ARC, Silva CAR, Martinelli LA (1990) Nature of POC transport in a mangrove ecosystem: a carbon stable isotope study. Estuar Coast Shelf Sci 30:641-645

Robertson AI (1986) Leaf-burying crabs: their influence on energy flow and export from mixed mangrove forests (Rhizophora spp.) in northeastern Australia. J Exp Mar Biol Ecol 102:237-248

Rodelli MR, Gearing JN, Gearing PJ, Marshall N, Sasekumar A (1984) Stable isotope ratios as a tracer of mangrove carbon in Malaysian ecosystems. Oceologia 61:326-333

Thomas CJ, Cahoon LB (1993) Stable isotope analyses differentiate between different trophic pathways supporting rocky-reef fishes. Mar Ecol Prog Ser 95:19-24

Thornton SF, McManus J (1994) Application of organic carbon and nitrogen stable isotope and $\mathrm{C} / \mathrm{N}$ ratios as source indicators of organic matter provenance in estuarine systems: evidence from the Tay estuary, Scotland. Estuar Coast Shelf Sci 38:219-233

Wolanski E (1995) Transport of sediment in mangrove swamps. Hydrobiologia 295:31-42

Submitted: November 20, 1997; Accepted: April 18, 2000

Proofs received from author(s): September 25, 2000 